\title{
MACIEJ JoŃCA
}

The John Paul II Catholic University of Lublin

\author{
THE EMPEROR TRAJAN AND THE PETITION \\ OF THE BITHYNIAN ATHLETES, (PLIN., EP. 118-119): \\ 'LEX RETRO NON AGIT'...?
}

The question whether there were any legal regulations in ancient Rome constituting a reflection of today's legal norms has been largely neglected in research, even though this area seems to offer a good potential for discussion. In the Polish work in the discipline this matter has been addresssed by Witold Wołodkiewicz ${ }^{1}$. The material he used in his analysis of the lex retro non agit principle may be supplemented with one more source - one which has been underestimated and referred to only incidentally, but which may effectively tip the balance of the discussion. Book Ten of Pliny's correspondence consists of letters addressed to Trajan, including some replies from the Emperor. It contains material which gives the perfect answer to the search for the origins of the lex retro non agit principle ${ }^{2}$.

1 W. WoŁodkiewicz, 'Lex retro non agit': sformułowanie w polskiej doktrynie prawniczej, «Zeszyty Prawnicze»1/2001, pp. 103-122. Understandably, Wołodkiewicz, focused on the analysis of the sources which could allow him to "isolate" the existence of the nonretroactivity principle in ancient Roman law. Indeed, all the sources, juxtaposed against one another and analysed, might give such an impression.

2 For comments on the complex history of the text see E.S. Stout, The Basis of the Text in Book X of Pliny's Letters, «TAPA» 86/1955, pp. 233-249. 
Around 109 AD Trajan sent Pliny the Younger as his special official to the province of Bithynia and Pontus ${ }^{3}$. Pliny's duties included the review of the municipal finances, investment control, and improving the operations of the 'central' administration. The issues on which he corresponded with the Emperor, unscrupulously taking advantage of their close relationship, concerned not only the serious and potentially controversial matters. In fact, he absorbed the Emperor's attention with relatively minor issues, for which, of course, he would be rebuked ${ }^{4}$.

As the governor's responsibilities included visiting the province and listening to the problems of its inhabitants, often the local community took the opportunity to petition him for an intervention with the Emperor. One of the problems requiring a solution was a specific request made by some professional athletes. In a letter to the Emperor dated $112^{5}$ we read the following ${ }^{6}$ :

\section{Pliny to the Emperor Trajan}

The winning athletes in the Triumphal Games, Sir, think that they ought to receive the prizes which you have awarded on the day they are crowned for victory. They argue that the actual date of their triumphal entry into their native towns is irrelevant; the date which matters is that of the victory which entitled them to the triumph. On the other hand, I point out that the name refers to 'triumphal entry' and so I am very

\footnotetext{
3 The date of Pliny's departure is debatable in the academic world. Most scholars, however, appear to accept 109 AD. See A.N. Sherwin-White, The Letters of Pliny. A Historical and Social Commentary, Oxford 1966, p. 81; J. Bennetr, Trajan. 'Optimus princeps'. Życie i czasy, Oświęcim 2015, p. 203.

4 J. BennetT, op. cit., p. 205.

5 See A.N. Sherwin-White, op. cit., p. 728.

6 For a critical analysis of the text see P. WeIss, Textkritisches zur Athleten-Relatio des Plinius (ep. 10,118), «ZPE» 48/1982, pp. 125-32.
} 
much inclined to think that their date of entry is the one we should consider.

They also claim awards for previous victories won in Games to which you have subsequently given triumphal privileges, arguing that if they receive nothing in Games which have lost these privileges after their victory it is only fair that they should have something for Games which afterwards acquire them. Here, too, I very much doubt whether any retrospective claim should be allowed and feel that they should not be given anything to which they were not entitled at the time of victory. I pray you, therefore, to think fit to resolve my difficulties and make it clear how your benefactions are to be bestowed ${ }^{7}$.

In the ancient Graeco-Roman world the word athletae used by Pliny in his letter, referred to sportsmen who 'had turned professional,' to use the modern terminology ${ }^{8}$. In Greek the noun athlon denoted a prize, while the verb athleo might be translated as 'I participate in a competition,' or as 'I endure or suffer something,' in the hope of winning a prize'.

\footnotetext{
7 Plin., ep. 118: C. Plinius Traiano Imperatori: Athletae, domine, ea, quae pro iselasticis certaminibus constituisti, deberi sibi putant statim ex eo die, quo sunt coronati; nihil enim referre, quando sint patriam invecti, sed quando certamine vicerint, ex quo invehi possint. Ego contrascribo 'iselastici nomine': itaque temporum eorum vehementer

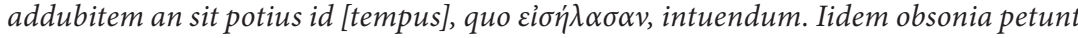
pro eo agone, qui a te iselasticus factus est, quamvis vicerint, ante quam fieret. Aiunt enim congruens esse, sicut non detur sibi pro iis certaminibus, quae esse iselastica, postquam vicerunt, desierunt, ita pro iis dari, quae esse coeperunt. Hic quoque non mediocriter haereo, ne cuiusquam retro habeatur ratio dandumque, quod tunc, cum vincerent, non debebatur. Rogo ergo, ut dubitationem meam regere, id est beneficia tua interpretari ipse digneris. Translation after Pliny, Letters. Books VIII-X. Panegyricus, transl. B. Radice, Cambridge, MA. and London, 2004, p. 311.

8 S.v. athletae, [in:] W. Smith, A Dictionary of Greek and Roman Antiquities, London 1882, pp. 166-167.

9 D. SŁAPEK, Sport i widowiska w świecie antycznym. Kompendium, Kraków-Warszawa 2010, p. 183.
} 
Hence the term athletai denoted athletes competing for pre-determined material rewards in disciplines requiring stamina and strength.

In Roman times the main occupation of the athletai was to prepare for a competition ${ }^{10}$. The Latin concept athletae appeared in the language of the Romans 'when the Greek agonistics had moved away from its ideals and became dominated by professionals, mainly boxers, wrestlers and pancratiasts. Most of them had a massive physique, as their height and weight decided whether they succeeded or not in the competition' ${ }^{\prime 11}$. Sport was not just their profession but the sole purpose of their lives. They practised even in winter, that is why they were known in Rome as the Herculanei and $x y s t i c i^{12}$. They worked on their skills under the supervision of professional trainers. The professional atheletes in the city of Rome established their own 'union,' shared a fund and had premises, the curia athletarum, at their disposal ${ }^{13}$, where they assembled to discuss current business. They were presided over by a 'president,' described in the sources as their xystarchus. In all this the athletae differed from amateur sportsmen, who were usually not so well organised (if at all), practised mainly for reasons of health and well-being, and if they participated in competitions they did not make sport their main source of income.

The Greek world had a long-established tradition of rewarding winners in the ancient Olympic Games with generous prizes and ample honours. The winner would be led into his native city in a lavish ceremony. A special gateway was made for him in the city walls, so that he could enter the city in a chariot drawn by four white horses. Next, he would take a triumphal ride along the main street of the city to stop at the temple of the local protective deity, where ceremonial hymns would be sung. Contests offering the opportunity for such a triumphal entry were called iselastic games (iselastici). Initially,

10 The emergence of professional athletes in Rome is dated to 186 BC - Liv. 39,22.

11 D. SŁAPEK, op. cit., p. 183.

12 Trainings would take place on roofed premises called the xystus - Vitr. de arch. 6,10 .

13 See M.L. CAldelli, 'Curia athletarum', ieraxystike synodos e organizazzione delle terme a Roma, «ZPE» 93/ 1992, pp. 75-87. 
there were four such events, that is the Olympic, Isthmian, Nemean, and Pythian Games ${ }^{14}$. In Roman times this honour was extended to other competitions ${ }^{15}$.

In the eyes of the Romans, the athletae were 'lumps of meat with broad shoulders, short necks, small heads and generally a low forehead'16, so they could not expect appreciation and respect. However, in the eastern provinces of the Empire they still enjoyed respect and admiration, thanks to the centuries of tradition. 'They were grand for their fame and the money they earned ${ }^{17}$. Those who won in the competitions received awards in the form of money, benefits in kind and exemption from public dues ${ }^{18}$. Their income could be very considerable. They were rewarded from resources at the disposal of the given municipality ${ }^{19}$. Such funds were raised mostly through public levies and taxes. The old privileges were upheld by Augustus and respected by his successors.

We don't know how far Trajan's innovations went in this respect. From Pliny's correspondence it appears that the Emperor might have increased the amount of the awards, raised some competitions to the rank of iselastic games and 'degraded' others ${ }^{20}$. The changes were laid down by law. The athletes, perhaps affiliated in a corporation (corporations?) established along lines similar to the one in Rome ${ }^{21}$, decided to voice their concerns with regard to the reforms, hoping to gain additional benefits. The respect which they enjoyed in their region certainly

14 Vitr., de arch. pref. 9.

15 Competitions would acquire the status of iselastic games solely through imperial decision. The material in the inscriptions confirms the Emperor's activity in this area. See CIL X 515. See also CIG 2932, CIG 3426.

16 D. SŁAPEK, op. cit., p. 184.

17 Ibidem.

18 For more on the subject of the prizes awarded to athletes in the ancient world, see ibidem, pp. 458-465.

19 H.W. Pleket, Some Aspects of the History of the Athletic Guilds, «ZPE» 10/1973, pp. 221-222.

20 E.G. Hardy, op. cit., p. $233 \$ 1$. See also A. SHERWIN-White, op. cit., p. 729; and P. WeIss, op. cit., pp. 125-126.

21 Cf. H.W. Pleket, op. cit., pp. 197-227. 
must have encouraged them to present their demands to the governor. The term obsonia used in the letter refers in the first place to monetary gratification. However, it is possible that the awards could have also included grain, wine and olive oill ${ }^{22}$.

The circumstances in which the letter was written meant that an exceptionally interesting legal problem had to be resolved - whether or not to grant permission for the retroactive application of the law. It is quite remarkable that Pliny bothered the Emperor with such a matter in the first place. The athletes' request cannot come as a surprise. After all, there were substantial sums of money at stake. Yet the very fact that Pliny, a man of considerable experience and well-versed in legal matters ${ }^{23}$, had doubts about the case, is noteworthy.

Book Ten of Pliny's correspondence with the Emperor shows that on numerous occasions he pestered Trajan with various issues which he should have taken care of by himself ${ }^{24}$. This situation seems to have been quite straightforward. Yet instead of issuing a brusque refusal to the 'greedy' athletes, Pliny wrote a letter demonstrating his indecision ${ }^{25}$. Its modern reader may be surprised that he was more concerned with the literal interpretation of the regulations relating to the rules of awarding prizes than with the problem of retroactivity of the law. Pliny's attitude can only be explained in one way: there was still no principle

22 E.G. Hardy, C. Plinii Caecilii Secundi Epistulae ad Traianum imperatorem cum eiusdem responsis, London,1889, p. $234 \$ 2$. Cf. H.W. Pleket, op. cit., p. 204 nt. 27.

23 For comments on the legal activity of Pliny the Younger see L. Winniczuk, Pliniusz Młodszy w świetle swoich listów i mów, Warszawa 1988, pp. 172-271.

24 J. BennetT, op. cit., p. 205.

25 Pliny's precautionary attitude might have also been caused by the fact that in the East the games were treated far more seriously than in Rome. Although Pliny might not have had the best opinion of such entertainment (cf.: ep., 4,22), he must have taken into account the circumstances in the province he was governing. See: P. WEIss, op. cit., p. 127. 
of non-retroactivity of the law, nor even a small token of this principle at the time!

Trajan's behaviour in this matter may seem just as astonishing. He responded to Pliny's query in a tone which might be considered more than restrained, giving him the following instruction:

\section{Trajan to Pliny}

In my opinion, awards in these Games should date from the winner's triumphal entry into his city and not before. Prizes awarded in Games to which I have granted triumphal privileges must not be given retrospectively where no such privileges existed previously. Nor does it assist the athletes' claim if they can gain no more awards in the Games from which I have removed triumphal privileges since their victories, for though the Games are now held under different conditions they are not required to hand back prizes previously won ${ }^{26}$.

Obviously, this is not an answer which would completely rule out Trajan's right to exercise an act of imperial grace. Yet it is difficult to relate it to an existing law or established custom prohibiting the retroactive application of the law. It is especially difficult to juxtapose the bottom

26 Plin., ep. 119: Traianus Plinio Iselasticum tunc primum mihi videtur incipere

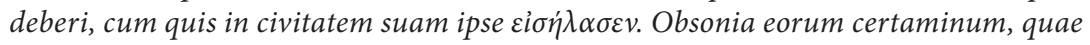
iselastica esse placuit mihi, si ante iselastica non fuerunt, retro non debentur. Nec proficere pro desiderio athletarum potest, quod eorum, quae postea iselastica non esse constitui, quam vicerunt, accipere desierunt. Mutata enim condicione certaminum nihilo minus, quae ante perceperant, non revocantur. Pliny, Letters. Books VIII-X. Panegyricus, trasl. B. RadiCE, Cambridge Massachusets-London 2004, p. 311-312. 
line of the Emperor's judgement with the existing legal interpretation or reasoning of the court. The Emperor's tone is sharp, almost severe ${ }^{27}$.

Trajan's decision should thus be treated as commonsensical, rather than as an interpretation of the law in force, which is in line with what we know from various sources about his character. In a late treatise attributed to Aurelius Victor and entitled Epitome de Caesaribus, we read the following on Trajan's intellectual potential: 'He highly esteemed very straightforward characters or men most erudite, although he himself was of slight theoretical knowledge and moderately eloquent ${ }^{28}$.

Before he voiced his opinion on complicated issues, Trajan consulted the eminent lawyers who constituted his consilium, as befits an emperor who held justice in high esteem. Council meetings were attended by renowned jurists such as L. Javolenus Priscus, L. Neratius Priscus, or Ti. Aristo ${ }^{29}$. If there had been just a trace of the principle of non-retroactivity extant in Trajan's times it would have been hardly imaginable for such eminent legal experts not to turn the Emperor's or his ministers' attention to the fact.

There is one more reason to be puzzled by the Emperor's response to the problem and reconsider it. As I have already said, he did not make any reference to existing laws or customs. This fact does not have to come as a surprise if we recall his other opinions, in which he consistently avoided making generalisations ${ }^{30}$. But he also steered clear of reference to ethics or philosophy, where he would have easily found good grounds

27 The Emperor might have been inclined to sound snappish due to the athletes' 'insolence,' poorly hidden behind a smokescreen of sophistic arguments. Cf. E.G. HARDY, op.cit., p. 235; A. Sherwin-White, op. cit., p. 731.

28 Aurel. Vict., de caes. 13.8: magis simpliciora ingenia aut eruditissimos, quamvis ipse parcae esset scientiae moderateque eloquens, diligebat. English translation after Thomas M. Banchich, Canisius College Translated Texts, Number 1. Canisius College. Buffalo-New York 2009 (2nd edition) http://www.roman-emperors.org/epitome.htm (accessed 3 Apr. 2018).

29 Se: J.A. CRook, 'Consilium principis'. Imperial Councils and Counsellors from Augustus to Diocletian, Cambridge 1955, pp. 50-54.

30 The most famous passage is on how to deal with the Christians - Plin., ep. 97. 
for his decision. He simply showed the Bithynian athletes that there was nothing more they could expect to get ${ }^{31}$.

Trajan's opinion in his letter to Pliny on the Bithynian athletes' request might have served as a precedent for the principle of non-retroactivity in Roman law. However, this did not happen for several reasons. Firstly, the tendency to apply the law retroactively was still very strong. Attitudes overtly incompatible with today's standards of the rule of law were enhanced by the political climate of the principate. The dissemination of the famous formula, 'the prince is not bound by laws' (princeps legibus solutus) is dated to the times of the African Severan dynasty ${ }^{32}$. It was regarded as yet another example of the Orientalisation of Roman law, moreover associated with growing decadence. In reality, however, all the predecessors of the Severans on the imperial throne, right back to Augustus, had disregarded the existing law whenever they found its provisions inconvenient.

Trajan's times saw the principate firmly established. Already in his lifetime referred to as "the best" (optimus), this Emperor did his utmost to reinforce his autocratic position in the state, yet at the same time maintained a tactful and elegant pose ${ }^{33}$, at a minimum cost to such a stalwart prince who knew exactly what he wanted. Yet politics has a characteristic feature - it is unpredictable. Both Trajan and his contemporaries who remembered the reign of Nero or Domitian were all too aware of that fact.

By introducing a universally applicable principle of non-retroactivity of the law, the Emperor would have limited his own freedom to take

31 That is why it is difficult to agree with the statement that Trajan listened to the athletes' requests 'with attention.' See D.G. KyLE, Sport and Spectacle in the Ancient World, Oxford 2015, p. 321. His answer t to Pliny testifies to the contrary.

32 D. $1,3,31$.

33 J. Bennett, op. cit., pp. 185-205. P. Veyne, Kim był imperator rzymski, [in:] Imperium grecko-rzymskie, Kęty 2008, p. 31. 
action in a radical way - especially in political matters ${ }^{34}$. Both Trajan as well as his subjects were fully aware of the vast scope of imperial power, which included the emperor's right to freely interpret and administer the law. In his Panegyric Pliny lavished sincere praise on the Emperor for 'ordering' his people to be free ${ }^{35}$. At the same time, Trajan promised to abide by the law for as long as he remained consul. Thereafter he chose not to ${ }^{36}$.

In the case of the Bithynian athletes, the Emperor prohibited the retroactive application of the law in a one-off decision, as he considered it the right and logical solution. Presumably, he must have also been irritated by the petitioners' 'insolent cunning.' However, nobody would have held it against him had he acted otherwise. And of course many of his contemporaries, with the athletes in the first place, would have been overjoyed.

\section{CESARZ TRAJAN W SPRAWIE BITYŃSKICH SPORTOWCÓW: 'LEX RETRO NON AGIT'...?}

\section{Streszczenie}

Materiał wykorzystany przez profesora Witolda Wołodkiewicza $\mathrm{w}$ jego badaniach nad zasadą lex retro non agit może być uzupełniony o jeszcze jedno źródło - niedoceniane, cytowane incydentalnie, ale jednak mogące nadać zupełnie nowy wymiar toczonej dyskusji. Dziesiąta księga korespondencji Pliniusza zawiera listy adresowane do Trajana oraz wybrane odpowiedzi władcy. Znalazł się tam materiał, który doskonale nadaje się do badań nad zasadą lex retro non agit. Wśród problemów wymagających rozwiązania Pliniusz natknął się na szczególną prośbę zawodowych atletów. Sportowcy poprosili go, by zaaplikował na ich korzyść pewne przepisy, które zostały właśnie wprowadzone przez

34 Ancient lawyers who supported non-retroactive laws could only rely on the feeble philosophical and ideological grounds. The Roman 'constitution' under the principate did not provide them with any such comfort. Cf. P. VEYnE, op. cit., pp. 9-73.

35 Plin., Paneg., 54,5. See also P. Veyne, op. cit., p. 31.

36 J. Bennett, op. cit., pp. 187-188. 
cesarza. Zarówno władca jak i jego namiestnik zgodzili się jednak, że w tym wypadku zastosowanie wstecznego działania prawa nie powinno mieć miejsca.

The Emperor Trajan and the Petition of the Bithynian Athletes: 'LEX RETRO NON AGIT'...?

\section{Summary}

The material used by Professor Witold Wołodkiewicz in his analysis of the lex retro non agit principle may be supplemented with one more source - one which has been underestimated and referred to only incidentally, but may effectively tip the balance of the discussion. Book Ten of Pliny's correspondence consists of letters addressed to Trajan, including some replies from the Emperor. It contains material which gives the perfect answer to the search for the origins of the lex retro non agit principle. In a list of unresolved issues Pliny mentions a specific request made by professional athletes, who wanted him to apply some regulations which the Emperor had just instituted, as grounds in their favour. But both the Emperor and Pliny, his governor for Bithynia, concur that in this case it would be inadmissible to make the new provisions retroactive.

Słowa kluczowe: prawo rzymskie; zasada nieretroakcji; korespondencja Pliniusza i Trajana.

Keywords: Roman law; principle of non-retroactivity; Pliny's correspondence with Trajan.

\section{Bibliography:}

Bennett J., Trajan. 'Optimus princeps'. Życie i czasy, Oświęcim 2015, p. 203. M.L. CALDELli, 'Curia athletarum', ieraxystike synodos e organizazzione delle terme a Roma, «ZPE» 93/1992.

Своок J.A., 'Consilium principis'. Imperial Councils and Counsellors from Augustus to Diocletian, Cambridge 1955.

Hardy E.G., 'C. Plinii Caecilii Secundi Epistulae ad Traianum imperatorem cum eiusdem responsis', London 1889. 
Pleket H.W., Some Aspects of the History of the Athletic Guilds, «ZPE»10/1973, pp. 221-222.

Sherwin-White A.N., The Letters of Pliny. A Historical and Social Commentary, Oxford 1966.

SŁAPEK D., Sport i widowiska w świecie antycznym. Kompendium, Kraków-Warszawa 2010.

Smith W., A Dictionary of Greek and Roman Antiquities, London 1882

Sтоuт E.S., The Basis of the Text in Book X of Pliny's Letters, «TAPA» 86/1955, pp. 233-249.

Veyne P., Kim był imperator rzymski?, [in:] Imperium grecko-rzymskie (Greco-Roman empire), Kęty 2008.

WeIss P., Textkritisches zur Athleten-Relatio des Plinius (ep. 10,118), «ZPE» 48/1982, pp. 125-32.

Winniczuk L., Pliniusz Młodszy w świetle swoich listów i mów, Warszawa 1988

WoŁodKIEWICZ W., 'Lex retro non agit': sformułowanie $w$ polskiej doktrynie prawniczej, «Zeszyty Prawnicze»1./2001, pp. 103-122. 